\title{
NETWORK ORCHESTRATION: VODAFONE'S JOURNEY TO GLOBALIZATION
}

\author{
Ayse Saka-Helmhout Christopher J. Ibbott
}

\begin{tabular}{|l|l|}
\hline Nijmegen School of Management & Surrey Business School \\
Radboud University & University of Surrey \\
PO Box 9108 & Guildford \\
6500 HK Nijmegen & Surrey GU2 7XH \\
& UK \\
\hline Tel: +31-24-3613079 & $+44-7785-363466$ \\
\hline Email: $\underline{\text { a.saka-helmhout@ fm.ru.nl }}$ & Email: $\underline{\text { c.ibbott1@ gmail.com }}$ \\
\hline
\end{tabular}

Published in the Orchestration of the Global Network Organization issue of Advances and International Management,

Edited by Torben Pedersen, Markus Venzin, Timothy M. Devinney \& Laszlo Tihanyi

Please reference as follows:

Saka-Helmhout, A. and Ibbott, C. J. (2014). 'Network orchestration: Vodafone's journey to globalization', in T. Pedersen, M. Venzin, T. M. Devinney and L. Tihanyi (eds), Orchestration of the Global Network Organization. Advances in International Management, 27: 123-149. Amsterdam: Elsevier. 


\title{
NETWORK ORCHESTRATION: VODAFONE'S JOURNEY TO GLOBALIZATION
}

\begin{abstract}
This investigation provides an understanding of network orchestration as an impersonal, primordial driving force that challenges the view in organizational design that assigns human choice and deliberate intention a central role. The study highlights the importance of emerging strategy and the unintended consequence in bringing about a desirable outcome in MNCs' efforts to coordinate and integrate globally-dispersed capabilities. It is based on a longitudinal action research that embraces a period of transformational change between Vodafone and Ericsson to achieve cash synergies in mobile network operations globally. The findings indicate that enabling knowledge mobility, appropriating knowledge, and fostering network stability contribute to a successful economic performance as interactive, self-governing processes of network orchestration. Accordingly, we conclude that the processes of network orchestration must be understood as driven by choice sets taken while creatively coping with change rather than as primarily choice sets deliberately taken in the sequential pursuit of goals.
\end{abstract}

Keywords: Network orchestration, Vodafone, inter-firm relationships, knowledge mobility 


\section{Introduction}

There has been substantial research on various multinational corporation (MNC) configurations in their link to identifying and leveraging capabilities (e.g. Prahalad and Doz, 1981; Bartlett and Ghoshal, 1989; Hedlund, 1994; Gulati et al., 2000). Regardless of whether the MNC is conceptualized as a set of internalized cross-border transactions (Buckley and Cason, 1976), a differentiated network (Ghoshal and Nohria, 1989; Nohria and Ghoshal, 1997), or a social community that crosses national boundaries (Kogut and Zander, 1992), the ability to leverage dispersed capabilities effectively is seen by most international business (IB) scholars as a key source of competitive advantage for MNCs (Zander, 1999; Ernst and Kim, 2002). The significant idea here is that the structural pattern of a firm is unique, and has the potential to confer competitive advantage.

Although the work on organizational design carried out in IB between 1970 and 1990 has had a significant impact on the IB field and has largely faded since, it continues to have a strong influence on organization theory. Network forms of organization, typified by reciprocal patterns of communication and exchange (Powell, 1990; Powell et al., 2005), are seen as reshaping the global business architecture and marking the current period by their growing prevalence (e.g. Monge and Fulk, 1999; Parkhe et al., 2006). However, much of the theorizing on organizational design rests on the central role assigned to human choice and deliberate intention (e.g. Child, 1972; Pettigrew, 1987; Whittington, 1988). It is argued that deliberate actions of individuals determine the success and/or failure of organizations. Outcomes tend to be attributed to conscious choices, and purposeful actions of individuals (Chia and Holt, 2009). The same can be observed in accounts of network orchestration by MNCs (e.g. Dhanaraj and Parkhe, 2006). There is little room for theorizing the unexpected effects of unintended consequences of deliberate choices (MacKay and Chia, 2013). In this chapter, our objective is to show an interactive process of network orchestration that combines choice and change in an 
unexpected way to produce a desired organizational outcome. Network orchestration is defined by those who assign a heroic status to agency, i.e. uphold the view that the deliberate actions of individuals determine the success or failure of an organization, as coordinating knowledge mobility, appropriating knowledge, and fostering network stability (Dhanaraj and Parkhe, 2006). Unlike arguments that celebrate the purposeful design processes led by hub firms in the formation and growth of a network (Dyer and Singh, 1998; Rowley et al., 2000), we highlight the importance of emerging strategy and the unintended consequence in bringing about a desirable outcome in MNCs' efforts to coordinate and integrate globally-dispersed capabilities.

We present a framework for network orchestration by drawing on organization theory in the following section. This is followed by an empirical illustration of key orchestration processes that Vodafone performed to create cash synergies in its key mobile network of infrastructure suppliers. The fourth section concludes the chapter by presenting the implications for IB of network orchestration.

\section{Network Orchestration}

There is increasing attention given to networks in which hub firms (Jarillo, 1988)—prominent actors (Knoke, 1994), flagship firms (Rugman and D'Cruz, 2000), or network orchestrators (Hacki and Lighton, 2001)—lack the benefit of hierarchical authority (e.g. Fulk, 2001). With widespread disintegration of value chains in many high-tech industries (Lorenzoni and BadenFuller, 1995), the significance of network orchestration has become more prominent. The paradox here is how a hub firm or a network orchestrator coordinates and influences other network members over which it has no hierarchical control to achieve economic benefits.

Organization theory literature highlights both chance and prior history, that is path dependence (Burton et al., 2002), and purposefully designed processes that are led by hub firms in the formation and growth of a network (Dyer and Singh, 1998; Rowley et al., 2000). In the 
intentional view, hub firms are seen to possess the attributes necessary to lead the process of pulling resources and capabilities of network members. As network orchestrators, they aim to create and extract value from the network by integrating and coordinating processes, resources, and assets (Hinterhuber, 2002). Intermediate levels of control and incentives in network organizations do not necessarily equate with overall inefficiency of such a structure (Demil and Lecocq, 2006). Mutual dependence, strong personal relationships and reputation preclude agents from pursuing their own interests exclusively (Powell, 1990; Jones et al., 1997). However, in order to create value in such structures, it is commonly argued that there needs to be deliberate, purposeful action (e.g. Kogut, 2000). In the context of network orchestration, these are hypothesized as i) coordinating knowledge mobility, ii) appropriating knowledge, and iii) fostering network stability (Dhanaraj and Parkhe, 2006).

\section{Mobilizing knowledge}

Mobilizing knowledge is defined as the 'ease with which knowledge is shared, acquired, and deployed within the network' (Dhanaraj and Parkhe, 2006: 660). This is necessary as significant value cannot be created where knowledge is retained by each network member. Hub firms are able to assess the value of relevant knowledge at different points in the network and to coordinate its transfer where it is needed (Gulati, 1999). They tend to follow three specific processes to mobilize knowledge: knowledge absorption, network identification, and interorganizational socialization (Dhanaraj and Parkhe, 2006). Knowledge absorption involves combining existing capabilities in new ways (Kogut and Zander, 1996). By establishing a common identity, hence confidence, among network members, a hub firm encourages open sharing of valuable knowledge (Dyer and Nobeoka, 2000). This knowledge tends to be mobilized through socialization, that is formal and informal linkages, among network participants (Brown and Duguid, 2000).

Appropriating knowledge 
Appropriating knowledge in network orchestration involves governing a network member's ability to capture value generated by mobilized knowledge (Teece, 1986, 2000). In its application to networks, appropriating knowledge implies evenly distributing the value created from knowledge mobility through an appropriability regime set up by the hub firm (Dhanaraj and Parkhe, 2006). This suggests a broad, consensual framework that averts any attempt to act opportunistically or leak information to external parties by the partners (Mowery et al., 1996). Dhanaraj and Parkhe (2006) suggest trust, procedural justice, and joint asset ownership mitigate concerns in appropriation. Social interactions that foster trust and reciprocity among network members are crucial in minimizing the risk of opportunistic behaviour (Gulati et al., 2000). A network orchestrator serves the role of a champion in building up this trust. Procedural justice or the fairness of the decision process encourages voluntary cooperation (Sheppard and Tuchinsky, 1996). This can be enacted by hub firms through network resource allocation, conflict resolution decisions, and consistency in decision making (Kim and Mauborgne, 1991). Dhanaraj and Parkhe (2006) also purport that joint asset ownership, which is commonly observed in networks, can reduce the risk of responsibility shirking, create room for joint problem solving, and provide incentives for sharing rewards.

\section{Fostering network stability}

The third task in network orchestration is fostering network stability that enables growth and flexibility for members to enter and exit the network (Dhanaraj and Parkhe, 2006). This rests on the assumption that loosely-coupled networks may experience unstable linkages encouraging, for instance, defection of network partners to other networks (e.g. Uzzi, 1997). The type of coordination displayed in the network is acknowledged to be one of 'subtle leadership' (Orton and Weick, 1990) rather than management. In other words, each network member is able to take initiatives. Change in the membership of a network through isolation, migration, cliques, and attrition poses a challenge to value creation (e.g. Lorenzoni and 
Lipparini, 1999), limiting opportunities for the creation of social capital (e.g. Inkpen and Tsang, 2005). The task of a hub firm as an orchestrator is to i) enhance or sustain reputation so that network members see a benefit in maintaining their links (Stuart, 2000), ii) encourage forwardlooking expectations of gains, and iii) promote multiplexity or interdependencies among network members through, for instance, multiple projects in order to reinforce ties (Kenis and Knoke, 2000).

In line with most previous research in organizational design, the three processes of network orchestration are perceived as planned, intentional actions. It is assumed that atomistic, rational calculation or a proactive ability to intentionally create, adapt, and control a specific network structure characterizes the process (e.g. Rowley et al., 2000). It is also contended that networks forms of organizations are driven initially by path-dependent processes, and subsequently adopt intentional management (Hite and Hesterly, 2001). Although we see the

role of human agency, choice, and deliberate intention in explaining the conduct of organizations as significant, we do not see decisive interventions as necessarily bringing about a desired state of affairs. Rather, we acknowledge the unintended effects of deliberate choices that contribute to shaping organizational circumstances (MacKay and Chia, 2013). The network orchestration processes that we highlight at Vodafone capture the very act of choosing a particular strategy in response to a specific objective that generated an unintended network form of organization.

\section{Research Methods}

We draw on a longitudinal action research, embracing a period of transformational change (December 1998 to November 2000) between two MNCs, Vodafone Group Plc. ("Vodafone") and Telefonaktiebolaget LM Ericsson, i.e. more specifically LM Ericsson AB (“Ericsson"). The transformational change was motivated, through a network infrastructure supply chain, by 
the Vodafone corporate objective to achieve cash synergies in its mobile network operations globally. Ericsson was a major supplier to Vodafone of said infrastructure and related services. The second author was the inaugural and co-leader of the initiative on behalf of Vodafone supported by an Ericsson counterparty. Though the primary stimulus was Vodafone, the two MNCs resolved to adopt a collective strategy to globalize their business relationship, recognizing and accepting that the financial benefits arising might be asymmetric.

It is noteworthy that the contextual background of the case company changed over the transition period. The initial Vodafone country quorum comprised the UK, Holland, Greece and Australia and the corresponding Ericson operations. Vodafone subsequently merged with AirTouch Communications, Inc. (“AirTouch”) of California (1999), and this combination later acquired Mannesmann AG ("Mannesmann") of Germany (2000). The consequence of this acquisition was the expansion in the number of Vodafone operators, ten in the longitudinal period of transition, i.e. the phase terminating when the interorganizational and inter-company relationships within each organization had evidenced transformed practices. Subsequently, two additional infrastructure suppliers became engaged with this synergy initiative. The Mannesmann AG acquisition resulted further in a range of synergy targets being committed to the financial markets.

In 1998, the second author as the IT and Project Management Director in Vodafone (UK), in advance of an impending merger with AirTouch, assumed responsibility for the achievement of the Vodafone financial targets. These could only be achieved through mobilizing the commitment of the operating companies that actually transacted business locally with Ericsson.

Data collection comprised a chronological sequence of all key meetings, with the venue and the purpose thereof, of the Vodafone and Ericsson members by organizational position, 
the Minutes of the meetings, and data sources and notations. Table 1 lists the chronology of all meetings in the case company.

Insert Table 1 about here

Of note are the Global Supply Chain Management (GSCM) and eRelationship meetings supplemented by a series of country visits conducted by the second author. The purpose of the country and ad hoc meetings by the second author was to support the promotion of the infrastructure supply chain globalization initiative, and to establish transparency and trust to bring on board the local operating companies in the transformational activities. For data sources more generally, reference was made to memorandums, exchanges/interactions at meeting venues, forums, video recordings of presentations, and emails.

The second author was present at all listed meetings save for two, the Global Cost Synergies meeting in the UK in which he was a part-time attendee and that of April 2000. Throughout the longitudinal period of the transformation, the GSCM meeting remained the main coordination focal point to which the virtual works streams were subordinated, to which progress was reported and from which new initiatives were launched. The second author participated in all the eRelationship virtual work stream meetings and was in the latter stages appointed as its chairman. None of the meeting minutes were prepared by the second author. The meeting facts and observations were confirmed and/or supplemented by the observations and/or input noted by the actors present at the meetings.

Whilst this case study provides for the opportunity of deep insight given the leadership role and participation of the second author, it too has the potential disadvantage of introducing bias. In mitigation thereof and post the case analysis, the second author held a workshop for the purpose of validating outcomes. The workshop was attended by the Ericsson Global 
Contact (a Managing Director based in the UK), another senior Ericsson Contact (a Managing Director also based in the UK), an Ericsson Director from Sweden, a Vodafone Customer Executive based in the UK and two academic experts, who all confirmed the facts. For example, one of the Supplier Global Contacts stated 'the Programme has, during the past two years, strengthened the relationship the Customer and Supplier in a way that never would have been possible in a purely commercial relationship'.

\section{Illustration of Network Orchestration: Vodafone's Inception of a Requisite Organization}

By January 1998, the second author, as the IT and Project Management Director in Vodafone Limited (the UK mobile operating company) had initiated the functional transformation of procurement to a supply chain function, including for the provision of mobile network infrastructure sourced from Ericsson (Supplier). The infrastructure included mobile network equipment, software and a number of related supporting services. This activity was to transform and optimize supply, deploy processes and practices locally in addition to contributing to the achievement of the cost reductions sought by Vodafone.

An illustration of the point is the deployment of base station equipment in containers to field locations adjacent to masts on which the antennas are mounted. Hitherto, Vodafone procured to its warehouse the container and all equipment/parts to be installed therein. Then either field engineers assembled, installed and tested the equipment/parts locally in the warehouse, after which the completed container was transported to its assigned field location, or the container and the equipment/parts were all shipped unassembled to the field location and the installation and testing process was carried out there. This led to variability in the standards of quality and physical configuration of the installation owing to undefined assembly and test instructions, as well as costs in deploying field engineers in this mode. The transformed supply chain alternative was to contract Ericsson to source its own and all other required third party 
equipment/parts and to build, integrate and commission/test the configuration in a factory environment according to defined assembly, test and quality processes, after which they could organize the shipment of the completed container directly to its assigned field location. The impact was to relieve Vodafone of the cost of all component procurement, warehousing and the deployment of field engineers to system build and test, and to achieve higher quality and consistent factory output delivered directly to site.

Whilst perhaps not unique in practice, these and the ensuing other changes in the supply chain context marked the transformation and optimization of extant working processes and practices within and between operating divisions in Vodafone UK, namely supply chain, technology and operations. The inter-MNC processes and practices were enhanced too, not to mention that Ericsson was the benefactor of an increased services business. Although there was resistance to the variant propositions within Vodafone, business ambitions were realized by adopting an inclusive, progressive and incremental approach. In May 1998, the Board of Vodafone Limited approved the second author's proposals for a UK policy on the separation of roles and responsibilities of Supply Chain Management and the Technology.

In the latter part of 1998, and in advance of the impending merger of Vodafone with AirTouch Communications Inc. of California, the anticipated benefit of enhanced cost synergies between the extant Vodafone mobile operating company interests and those of AirTouch was promoted by the Vodafone M\&A team. A financial benefit of the merger was anticipated to be the opportunity for enhanced synergies from lessons learned and shared due to the increase in number of mobile network operators in the merged businesses that may otherwise not have been realized. Initially, this prompted discussions internal to Vodafone between the extant operators led/hosted by the second author. However, all parties were constrained from commercial information exchanges due to each country operation being bounded by Non-Disclosure Agreement (NDA) obligations in the local contracts with Ericsson. 
This quorum of operators and the percentage equity ownership of Vodafone Group Plc. at that time were the UK (100\%), Libertel of Holland (70\%), Panafon of Greece (55\%) and Vodafone Australasia (to include Fiji) (91\%), each of which were existing Ericsson network infrastructure customers. The second author also established, with the Ericsson newly appointed global leader, a shared interest and a strategy in seeking to globalize interorganizational commercial relationships by enhancing all aspects of the (end-to-end) network infrastructure supply chain management processes from the source of supply through to network deployment and the support thereof such as warranties, software updates, and reverse logistics.

There were no preordained agreed scope of work, organization structures, budget, levels of authority, or formal governance arising from the decision to implement a global supply chain. In other words, the intra- and interorganizational processes and commercial outcomes were not envisaged, prescribed or planned. Rather, there was a polarizing Vodafone objective to attain cash synergies in the network infrastructure supply chain and with an acceptance that the benefits arising thereof may be asymmetric and not shared.

With the agreement of the Ericsson global leader, the second author invited the current Vodafone local operating company interests and their local Ericsson counterparts to the joint Vodafone-Ericsson inaugural Global Supply Chain Management (GSCM) meeting to be hosted by Vodafone Limited. In February 1999, to overcome the aforesaid issue of confidentiality, it was a requirement that each attending company sign a group NDA that enabled the open sharing between the parties of all hitherto confidential commercial information. This was the first globalizing step of an emerging and new interorganizational relationship, each organization being treated as a homogenous whole and each country identified jointly as a single entity for the purposes of the new journey. This forum was to become the catalyst for transformational change within which social and intellectual capital could develop through 
sharing of knowledge and building of a common identity. These were hindered in the former silo-based disaggregated interorganizational relationships.

To that end, it was agreed that the GSCM forum would be a Steering Group and that detailed (virtual) assignments should be assigned and delivered jointly by the Vodafone and Ericsson participating local companies. It was further agreed that the second author, through the UK Company, and with the Ericsson global leader would conclude the first commercial Global Agreement. This was an initiative that had already been underway in the UK and the outcome of which would now be of synergy benefit to the participating Vodafone operating companies, as the variant interorganizational relationships would, through this unified collaboration, be treated as one by Ericsson.

A number of virtual work streams were initiated to include global terms and conditions for products procured from Ericsson (Global Price Book), to converge radio base station equipment configurations, to analyze and propose a network-converged switching requirement, and to establish common software, audit test and delivery methodologies (see Table 2).

Insert Table 2 about here

A work stream, assigned by country, consisted of a combination of local resources of both MNCs and the support, as required and decided by those leading the work stream, of other interested countries. It was agreed that progress of these and any other/new work streams would be reported at the GSCM meetings. Virtual teams could be independently set up with invitees of a given country member's choice regardless of whether or not these members attended the GSCM meetings.

Of significance here was the work stream that was to lead to the introduction, by the second author, of the concept of eRelationship (previously known as Groupware). The 
eRelationship environment was created and hosted by Ericsson on an IT platform in Stockholm in 1999. It was a bi-directional web portal or a virtual environment for both global and local interorganizational information and knowledge sharing, all intended to epitomize the relationship within and between the two organizations. Key, however, was that the placement, the management thereof, of information and access rights were to be governed by the contributors utilizing a set of software tools. There was to be no centralized control. Save for commercially sensitive information, the ethos was that all information would be accessible by all employees of either MNC, whether or not they were involved in the Vodafone-Ericsson business relationship. This was achieved. A further objective through the virtual work streams was to promulgate new practice and learning to others in the end-to-end supply chain within and between the MNC organizations for the betterment of their MNC and/or country operations.

An impact of eRelationship was the increase in the unrestricted flow and/or exchange of unfiltered information within and between both MNCs. This was an open inter- and intraorganizational model, beyond the control of the HQ of both MNCs. It extended to all registered intranet users who were not engaged in this particular business relationship. The value creation of intellectual capital was under virtual control, but it was reinforced by the evolved social capital, the momentum of which could be extracted from the various global forums and meetings that also became a catalyst for engagement.

By May 2000, the eRelationship focus became formalized with clarity of strategic intent as is illustrated by the following highlights presented jointly by the Vodafone and Ericsson project leaders for the approval of the virtual working group.

“The Vodafone (Customer) - Ericsson (Supplier) Global Portal must reflect the entire global relationship, in all its aspects, between Vodafone and Ericsson"; "Further, it is the aim that this eRelationship virtual environment becomes that 
natural primary source of information and communication between the organizations, and as such is not constrained by time and/or location"; "it is anticipated that arising from this new paradigm will be the mutual requirements for changes in process, practices and organizations"; "In particular, this capability is crucial to the sustainable support of all global virtual workstreams and initiatives under the guidance of the GSCM virtual leadership". (Ibbott, 2001: 262-263)

As a prime mover for the Vodafone Group, the second author became the catalyst within the network of its operating companies for the transformation of the network infrastructure supply chain, which was enabled through eRelationship to garner support from a critical mass of operating companies. None of the operating companies directly reported to the second author. Yet they were, in combination, the source of the realized cash synergies against which they were targeted in the Group business, because they were the ones to transact with Ericsson locally. The role required a non-hierarchical lead, transcending the vertical company hierarchies of the Vodafone operating companies and interceding in their collective local disaggregated business relationships with Ericsson.

In order to create the global interorganizational community, following the inaugural meeting in the UK, the venue for the GSCM meetings was agreed to be variously convened in the countries of the participating joint MNC operating companies to engender an esprit de corps among the participants - to additionally include Holland, Greece, Sweden, Egypt, Australia, Portugal and Romania. Although the forum comprised of actors of variant hierarchical position, it had no formal status. The local companies of the MNCs took decisions collectively in these meetings to which the second author offered guidance and/or ascent as appropriate. This was, in practice, a conformant accession, by the Vodafone operating companies, of local decision making authority to the globalizing leadership on matters of commerce and conditions related 
thereto e.g. the Global Price Book and its requirements for variant practices as a quid pro quo in return for supplier concessions. These GSCM meetings were observed to be highly inclusive regardless of country-of-origin, and company and/or job role. Of note too, was that the small global team of the second author comprised actors and/or secondees from Vodafone operating companies' supply chain or technical teams, recommended by the extant global team members and supported by the operating companies.

The case data shown in Table 3 provide clear evidence of the nature of the boundary crossing as observed in multi-level job roles of participating actors.

Insert Table 3 about here

The vertical axis depicts the horizontal organization mix and hierarchical job roles within each MNC (Vodafone as Customer and Ericsson as Supplier). The horizontal axis documents the number of attendees at each of the GSCM meetings and of the eRelationship working group. In this context, the network organization was the plethora of the engaged and non-engaged operating companies of each of the MNC with Group/HQ engagement/support, whilst the eRelationship was an enabling means for the sharing of information and knowledge both globally and on projects locally.

Through the strength of the boundary-crossing actors in the horizontal interorganizational structure, the local objections, resistance and/or reticence were overcome, for example, through the release of the Global Agreement. This Agreement provided for a consolidation of equipment and a limitation of configuration diversity in return for unified pricing and commercial terms. The following quote from the Listing of Particulars (page 9) offers a quantum to the magnitude of the synergy expectations in anticipation of the Vodafone AirTouch Plc. offer for Mannesmann AG: 
"The Board expects the benefits of this transaction to generate synergies of approximately $£ 500$ million on a proportionate after tax cash flow basis in 2003 (with approximately 20 per cent of such synergies coming from increased revenues, 40 per cent from cost savings and 40 per cent from capital expenditure savings) and approximately $£ 600$ million on a proportionate after tax cash flow basis in 2004 (with approximately 25 per cent of such savings coming from increased revenues, 40 per cent from cost savings and 35 per cent from capital expenditure savings).”

The network infrastructure synergies discussed here were substantially contributions made to the capital expenditure objectives, though operating expense activities were also pursued. Vodafone reported, in its Interim Results Release for the Six Months to 30 September 2002, "Good progress has been made on the synergies arising from the Mannesmann transaction. It is expected that the $£ 500 \mathrm{~m}$ of forecast post-tax cash flow synergies for the year ending March 2003 will be exceeded”. Further, in its 2004 Annual Report Vodafone stated "Mannesmann has been integrated into the Group and the expected synergies for the year ended 31 March 2004 announced at the time of the acquisition have been achieved, exceeding the target mainly as result of higher savings from capital expenditure, handset procurement and additional revenue opportunities". The Customer-Supplier GSCM forum enabled the transfer of experiential knowledge and the dispersion of lead responsibilities of internationalization to actors representing various customer operating company equity interests. For instance, as the Group Supply Chain Management (SCM) Director of Vodafone Procurement Company (VPC), Detlef Schultz, indicates, the supply chain management resulted in a paradigm shift by 2008. VPC became a strategic sourcing center. By 2011, the company was leveraging synergies beyond boundaries. The VPC was targeting new areas of spend (presentation by the GSCM Director). By the same token, the Customer senior lawyer from the US perceived the GSCM meetings as follows. 
"For the first time, there was vigorous dialogue among the Customer's operating companies regarding the vendor's products, performance, price, and future plans...[The second author] moderated the discussions, planned the ongoing meetings and work of the (global Customer-Supplier) team... These small beginnings yielded large results. Through the improvement in communication and reductions in unnecessary product (configurations), the vendor was able to improve its efficiency...the bulk of the improvements in pricing came from the supply chain process".

As a point of note, in 2001 Vodafone introduced formal governance in pursuit of a Mannesmann synergy commitment that formalized the relationship between the Vodafone Group functions and its local operating companies. Of developmental relevance to the period beyond the case study, was the formation of the SCM Council and the IT and Technology (ITTM) Council; the second author participated in both forums. These forums decided jointly on matters of technology, its sourcing and deployment, to which the Vodafone operating companies were obliged. The informal virtual organization remained intact and continued to function below the SCM Council, which comprised of representatives of large OpCos, representatives of smaller OpCos, Group CTO, and the Group Technology representatives. This body served to ratify what was informally agreed or to assert decisions taken outside the Council. The second author represented, on behalf of the informal virtual organization, proposals for adoption on Group matters relating to the mobile network infrastructure.

\section{Discussion}

We began by asking what role network orchestration serves in MNCs' coordination and integration of capabilities that are globally dispersed. Our findings, as summarized in Table 4, progress a perspective on MNC configuration that takes into account the unexpected effects of 
unintended consequences of deliberate choices. This approach celebrates the importance of emerging strategy and unintended consequence in bringing about a desirable outcome in MNCs' efforts to coordinate and integrate globally dispersed capabilities.

Insert Table 4 about here

Vodafone, in agreement with Ericsson, played a pivotal role in the formation, growth, and success of its network infrastructure. As the case suggests, knowledge absorption and interorganizational socialization are significant in enabling knowledge mobility. GSCM meetings, work streams (which reflected boundary-crossing activity), and the eRelationship platform enabled the exchange of commercial knowledge and the development of a common understanding relevant for the case initiative. What is important to note here is that the hub firm or the orchestrator - Vodafone - neither aimed to control knowledge mobility, nor was it in a position to assess the value of relevant knowledge at different points in the network. Each local company was treated as an independent entity or node rather than as part of a hierarchical unity of command. Although the Vodafone objective was to attain cost synergies, this was pursued through mutually respected horizontal relationships. The role of Vodafone was one of a catalyst for learning at the organization's boundaries (Lyles and Salk, 1996). Each virtual work stream, led by a self-organized country and including local members from Vodafone and Ericsson, leveraged resources and interacted horizontally with other teams in their base companies, and in the broader joint MNC communities, as necessary. This reinforced a common identity among network partners (Dhanaraj and Parkhe, 2006). The GSCM forum also served as a socialization platform that encouraged the accrual of social capital (Ahuja, 2000). 
Vodafone's effort in distributing value equitably in appropriating knowledge involved the signing of a group NDA. This was to facilitate the open sharing of confidential commercial information, and to dispel the fear that the openness of partners in the network would not be taken advantage of (Teece, 2000). Although there was a deliberate choice to attain cost synergies, it was well recognized by the partners that the benefits would be asymmetric. There was no conventional agreement around the provision of visibility or the sharing of the cost reductions achieved. It was simply acknowledged that any tangible and/or intangible benefits arising from joint endeavours would be retained solely by the party in question. For instance, Vodafone's equity-based grouping required the engagement of management teams of each entity who had to buy-in to ideas to support the organizational transformation. By contrast, Ericsson's fully-owned subsidiaries had less scope to resist the propositions. Voluntary cooperation was also encouraged through social interactions with partner firms and the use of trust and joint problem-solving that was championed by Vodafone. High levels of trust prevailed, in particular, among key Vodafone and Ericsson individuals, whose relationship dated back to 1983 .

What is striking in the case is that fostering network stability was not a critical task of the network orchestrator (cf. Kenis and Knoke, 2002). The interdependencies established among network members, or local operating companies of Vodafone and Ericsson, through GCSM meetings and virtual work stream activities convinced members of a benefit in maintaining their links. Reciprocity enabled continuity. Vodafone was tasked with delivering a reliable efficient network to its customers, and Ericsson had to provide its key customers such as Vodafone with reliable, cost-effective and technologically advanced products and support. However, the formalization of the network was never set as an objective. The emergent network, composed of the Vodafone global and virtual management team, Lead operating 
companies (supplier clusters) including Ericsson, Nortel, Nokia and Siemens, and remaining Vodafone operating companies, was an informal one (see Figure 1).

Insert Figure 1 about here

The network was self-governing to assure relevant inputs and inclusion in execution. The network orchestrator upheld the view that the emergent informal structure should remain nonhierarchical in operation. This was seen as contributing to the successful economic performance of the network. Although a formal governance structure (Supply Chain Management (SCM) Council, and IT and Technology Management (ITTM) Council) was subsequently introduced, this did not intervene with the informal functioning of the virtual organization.

The case reported here demonstrates an interactive process of creative evolution, i.e. choice and change interacting to produce consequences that influence organizational outcomes (the achievement of cost synergies) in an unexpected way (through the emergence of a network organization). It offers a process view that recognizes the importance of action, interaction, spontaneous change, and their unintended consequence. Although the intentional view offers insight into the reasons for Vodafone's search for an organizational means to achieve cost synergies, it is essentially limited in its ability to explain fully the emergence of a network organization to achieve such synergies. Throughout the transformation process, there was no predetermined underlying order that produced stable choice sets. Order emerged spontaneously as GSCM and work stream meetings were held. Therefore, we argue that the process of network 
orchestration must be understood as driven by choice sets taken while creatively coping with change rather than as primarily choice sets deliberately taken in the sequential pursuit of goals.

\section{Conclusion}

The IB literature is not foreign to the coordination tasks of managing a network of established foreign subsidiaries, and an analysis of the competitive advantages that arise from potential economies of scope (e.g. Ghoshal and Bartlett, 1990). An MNC's structure has been the most enduring idea of IB (Ghoshal and Nohria, 1993) up until the 1990s. Given the radical change in the way economic value is created, and empowered by the digital information technology, network organizations are taking a leading role in economic and social innovations (Birkinshaw and Hagström, 2000). Although the relevance of exploiting external resources (Teece et al., 1997), and the ability to integrate efforts of different actors (Grant, 1996) have been acknowledged, the processes in orchestrating a network remain fairly unarticulated and projected as predetermined and intended. Drawing on organization theory, we shed light on the process of network orchestration consisting of mobilizing knowledge, appropriating knowledge, and fostering network stability. We emphasize action and process as opposed to position and structure. Structure alone does not create the benefit, but the entrepreneurial approach of a hub firm to turn the structure into a benefit is noteworthy. Unlike other studies that focus on the deliberate acts and intended consequences of central firms to exploit and manage the network (e.g. Ahuja, 2000), we consider the unintended consequence of an intentional action, thus recognizing the reality of in situ responses of network orchestrators themselves.

We suggest that cultivating an internalized agility involving on-going creative adaptation is crucial to dealing with the unintended consequences of action in a world of increased adversity. We emphasize that organizations encourage innovation from within a 
global virtual community, where appropriate, void of pre-emptive structure, and mandates save for alignment on the strategic ambition. Unintended but strategically consistent outcomes can be a bonus from wherever and whomever they emerge. A hierarchical position/role is not an exclusive domain within which effective outcomes may emerge. The case study also illustrates that endeavours into uncharted areas of the business do not necessarily require detailed planning, but instead allow leadership to orchestrate and guide the situational dynamics. It helps to consider acknowledging the doctrine of equivalence of the emergent participant contributions, being constrained only by a positive progression and momentum towards that espoused and agreed strategy.

The case reported here considers the interworking of two (Supplier-Customer) MNCs within a specific set of circumstances. This limits our ability to generalize some of our findings. However, our fundamental message applies across the board, that a dynamic analysis of networks, which recognizes the reality of change in inter-firm network relationships (e.g. Kenis and Knoke, 2002) and the role of emergent strategy and unintended consequences of strategic change (e.g. Balogun and Johnson, 2005; Boisot and McKelvey, 2010), is a more representative way of understanding the way in which today's MNCs coordinate and integrate globallydispersed capabilities. Future research can seek to explore network orchestration processes in differently-sized organizations and sectors that are exposed to varying intensity of competition. This would help deepen understanding into the creative nature of network orchestration. 


\section{References}

Ahuja, G. (2000). Collaboration networks, structural holes and innovation: A longitudinal study. Administrative Science Quarterly, 45, 425-455.

Balogun, J. \&Johnson, G. (2005). From intended strategies to unintended outcomes: The impact of change recipient sense-making. Organization Studies, 26, 1573-1601.

Bartlett, C. \& Ghoshal, S. (1989). Managing Across Borders: The Transnational Solution. Boston: Harvard Business School Press.

Birkinshaw, J. \& Hagstrom, P. (2000). The Flexible Firm: Capability Management in Network Organizations. Oxford: Oxford University Press.

Boisot, M. \& McKelvey, B. (2010). Integrating modernist and postmodernist perspectives on organizations: A complexity science bridge. Academy of Management Review, 35, 415-433.

Brown, J. S. \& Duguid, P. (2001). Knowledge and organization: A social-practice perspective. Organization Science, 12, 198-213.

Buckley, P. J. \& Casson, M. (1976). The Future of the Multinational Enterprise. London: The Macmillan Press.

Burton, M. D., Sørenson, J.B. \& Beckman, C. M. (2002). Coming from good stock: Career histories and new venture formation. Research in the Sociology of Organizations, 19, 229-262.

Chia, R., \& Holt, R. (2009). Strategy without Design: The Efficacy of Indirect Action. Cambridge, U.K.: Cambridge University Press.

Child, J. (1972). Organization structure, environment, and performance: The role of strategic choice. Sociology, 6: 1-22.

Demil, B. \& Lecocq, X. (2006). Neither market nor hierarchy nor network: The emergence of bazaar governance. Organization Studies, 27, 1447-1466.

Dhanaraj, C. \& Parkhe, A. (2006). Orchestrating innovation networks. Academy of Management Review, 31, 659-669.

Dyer J.H. \& Singh H. (1998). The relational view: Cooperative strategy and sources of interorganizational competitive advantage. Academy of Management Review, 23, 660-679.

Dyer, J. H. \& Nobeoka, K. (2000). Creating and managing a high-performance knowledge sharing network: The Toyota case. Strategic Management Journal, 21, 345-368.

Ernst, D. \& Kim, L. (2002). Global product networks, knowledge diffusion, and local capability formation. Research Policy, 31, 1417-1429.

Fulk, J. (2001). Global network organizations: Emergence and future prospects. Human Relations, 54, 91-99.

Ghoshal, S. \& Bartlett, C. A. (1990). The multinational corporation as an interorganizational network. Academy of Management Review, 15, 603-625. 
Ghoshal, S. \& Nohria, N. (1989). Internal differentiation within multinational corporations. Strategic Management Journal, 10, 323-337.

Ghoshal, S. \& Nohria, N. (1993). Horses for courses: Organizational forms for multinational corporations. Sloan Management Review (Winter), 23-35.

Grant, R. M. (1996). Towards a knowledge-based theory of the firm. Strategic Management Journal, 17 (Winter Special Issue), 109-122.

Gulati, R. (1999). Network location and learning: The influences of network resources and firm capabilities on alliance formation. Strategic Management Journal, 20, 397-420.

Gulati, R., Nohria, N. \& Zaheer, A. (2000). Strategic networks. Strategic Management Journal, 21, 203-215.

Hacki, R. \& Lighton, J. (2001). The future of the networked company. McKinsey Quarterly, 3, 26-39.

Hedlund, G. (1994). A model of knowledge management and the N-form corporation. Strategic Management Journal, 15, 73-90.

Hinterhuber, A. (2002). Value chain orchestration in action and the case of the global agrochemical industry. Long Range Planning, 35: 615-635.

Hite, J. M. \& Hesterly, W. S. (2001). The evolution of firm networks: From emergence to early growth of the firm. Strategic Management Journal, 22, 275-286.

Ibbott, C. J. (2001). An IS-enabled model for the transformation and globalization of interorganizational and inter-company relationships. Unpublished DBA Thesis, Brunel University, UK.

Ibbott, C. J. (2007). Global Systems: The Vodafone-Ericsson Journey to Globalisation and the Inception of a Requisite Organisation. Palgrave Macmillan.

Ibbott, C. J., and O'Keefe, R.M. (2004). Transforming the Vodafone/Ericsson relationship. Long Range Planning 37, 219-237.

Inkpen, A.C. \& Tsang, E. W. K. (2005). Social capital, networks, and knowledge transfer. Academy of Management Review, 30, 146-165.

Jarillo, C. (1988). On strategic networks. Strategic Management Journal, 9, 31-41.

Jones, C., Hesterly, W. S. \& Borgatti, S. P. (1997). A general theory of network governance: Exchange conditions and social mechanisms. Academy of Management Review, 22, 911-945.

Kenis, P. \& Knoke, D. (2002). How organizational field networks shape interorganizational tie-formation rates. Academy of Management Review, 27, 275-293.

Kim, W. C. \& Mauborgne, R. A. (1991). Implementing global strategies: The role of procedural justice. Strategic Management Journal, 12, 125-143.

Knoke, D. (1994). Networks of elite structure and decision making. In S. Wasserman \& J. Galaskiewicz (Eds), Advances in Social Network Analysis, pp. 274-294. Thousand Oaks: Sage. 
Kogut, B. \& Zander, U. (1992). Knowledge of the firm, combinative capabilities, and the replication of technology. Organization Science, 3, 383-397.

Kogut, B. \& Zander, U. (1996). What do firms do? Coordination, identity, and learning. Organization Science, 7, 502-518.

Kogut, B. (2000). The network as knowledge: Generative rules and the emergence of structure. Strategic Management Journal, 21, 405-425.

Lorenzoni, G. \& Baden-Fuller, C. (1995). Creating a strategic centre to manage a web of partners. California Management Review, 37, 146-163.

Lorenzoni, G. \& Lipparini, A. (1999). The leveraging of inter firm relationships as a distinctive organizational capability: A longitudinal study. Strategic Management Journal, 20, 317-338.

Lyles, M. A. \& Salk, J. E. (1996). Knowledge acquisition from foreign parents in international joint ventures: An empirical examination in the Hungarian context. Journal of International Business Studies, 29, 154-174.

MacKay, R. B. \& Chia, R. (2013). Choice, chance, and unintended consequences in strategic change: A process understanding of the rise and fall of NorthCo Automative. Academy of Management Review, 56, 208-230.

Monge, P. R. \& Fulk, J. (1999). Communication technology for global network organizations. In G. DeSanctis \& J. Fulk (Eds), Shaping Organizational Form: Communication, Connection, and Community, pp. 71-100. Newbury Park: Sage.

Mowery, D. C, Oxley, J. E. \& Silverman, B. S. (1996). Strategic alliances and interfirm knowledge transfer. Strategic Management Journal, 17 (Winter Special Issue), 77-91.

Nohria, N. \& Ghoshal, S. (1997). The Differentiated Network: Organizing Multinational Corporations for Value Creation. San Francisco: Jossey-Bass Publishers.

Orton, J. D. \& Weick, K. E. (1990). Loosely coupled systems: A reconceptualization. Academy of Management Review, 15, 203-223.

Parkhe, A., Wasserman, S. \& Ralston, D. A. (2006). Introduction to special topic forum: New frontiers in network theory development. Academy of Management Review, 31, 560-568.

Pettigrew, A. (1987). Context and action in the transformation of the firm. Journal of Management Studies, 24, 649-670.

Powell, W. W. (1990). Neither market nor hierarchy: Network forms of organization. Research in Organizational Behaviour, 12, 295-336.

Powell, W. W., Douglas R. W., Koput, K. W. \& Owen-Smith, J. (2005). Network dynamics and field evolution: The growth of interorganizational collaboration in the life sciences. American Journal of Sociology, 110, 1132-205.

Prahalad, C. K. \& Doz, Yves L. (1981). An approach to strategic control in MNEs. Sloan Management Review, Summer, 5-13. 
Rowley T., Behrens D. \& Krackhardt D. (2000). Redundant governance structures: An analysis of structural and relational embeddedness in the steel and semiconductor industries. Strategic Management Journal, Special Issue 21, 369-386.

Rugman, A. M. \& D'Cruz, J. R. (2000). Multinationals as Flagship Firms. Oxford: Oxford University Press.

Sheppard, B. H. \& Tuchinsky, M. (1996). Micro OB and the network organization. In R. M. Kramer and T. R. Tyler (Eds), Trust in Organizations: Frontiers of Theory and Research, pp. 166-195. Thousand Oaks: Sage Publications.

Stuart, T. E. (2000). Interorganizational alliances and the performance of firms: A study of growth and innovation rates in a high-technology industry. Strategic Management Journal, 21: 791-811.

Teece, D. J. (1986). Profiting from technological innovation: Implications for integration, collaboration, licensing and public policy. Research Policy, 15, 285-305.

Teece, D. J. (2000). Managing Intellectual Capital: Organizational, Strategic, and Policy Dimensions. Oxford: Oxford University Press.

Teece, D. J., Pisano, G. \& Shuen, A. (1997). Dynamic capabilities and strategic management. Strategic Management Journal, 18, 509-533.

Uzzi, B. (1997). Social structure and competition in interfirm networks: The paradox of embeddedness. Administrative Science Quarterly, 42, 35-67.

Whittington, R. (1988). Environmental structure and theories of strategic choice. Journal of Management Studies, 25, 521-536.

Zander, I. (1999). How do you mean 'global'? An empirical investigation of innovation networks in the MNC. Research Policy, 28, 195-213. 
Table 1. Chronological sequence of all meetings

\begin{tabular}{|c|c|c|c|c|c|c|c|}
\hline Meeting category & $\begin{array}{c}\text { GSCM } \\
\text { Meeting }\end{array}$ & eRelationship & $\begin{array}{l}\text { Ad } \\
\text { Hoc }\end{array}$ & $\begin{array}{l}\text { Second } \\
\text { author } \\
\text { country } \\
\text { visits }\end{array}$ & Supplier & $\begin{array}{c}\text { New } \\
\text { GSCM } \\
\text { initiatives }\end{array}$ & Comments \\
\hline \multicolumn{8}{|l|}{ Meeting Dates: } \\
\hline February 25-26, 1999 & $x$ & & & & & & Inaugural GSCM meeting in Newbury, UK \\
\hline March 23, 1999 & & & & $x$ & & & Libertel in Maastricht, Holland \\
\hline April 14-15, 1999 & $x$ & & & & & & Maastricht, Holland \\
\hline May 26-27, 1999 & $x$ & & & & & & Athens, Greece \\
\hline July 26-27, 1999 & & & $x$ & & & & Former AirTouch properties in Amsterdam \\
\hline August 2, 1999 & & & & $x$ & & & Ericsson in Holland \\
\hline August 3-4, 1999 & & & & $x$ & & & Panafon and Ericsson jointly in Athens, Greece \\
\hline August 5-6, 1999 & & & & $x$ & & & Misrfone and Ericsson jointly in Cairo, Egypt \\
\hline August 13, 1999 & & & $x$ & & & & $\begin{array}{l}\text { Meeting that included eRelationship in } \\
\text { Stockholm }\end{array}$ \\
\hline September 2-3, 1999 & $x$ & & & & & & Nynashamn, Near Stockholm, Sweden \\
\hline September 10, 1999 & & $x$ & & & & & Inaugural meeting in Amsterdam, Holland \\
\hline September 14-15, 1999 & & & $x$ & & & & Global Cost No. 1 Synergies in Newbury, UK \\
\hline September 16, 1999 & & & & $x$ & & & Libertel meeting in Maastricht, Holland \\
\hline September 17, 1999 & & & & $x$ & & & Düsseldorf, Germany \\
\hline October 6, 1999 & & & & $x$ & & & Airtel only in Madrid, Spain \\
\hline October 11, 1999 & & $x$ & & & & & Amsterdam, Holland \\
\hline
\end{tabular}


\begin{tabular}{l|l}
$X$ & New infrastructure supplier presentation in
\end{tabular} Copenhagen, Denmark

Technical Operations Symposium in Newbury, UK

London, UK

GSM Systems Program Managers in

Stockholm

Telecel and Ericsson separately in Lisbon,

Portugal

Panafon and Ericsson jointly in Athens, Greece

TTS Global Workshop, Nr Stockholm

D2 meeting in London, UK

London, UK

Cairo, Egypt

Vodafone and Ericsson jointly in Sydney,

Australia

Ericsson jointly with Vodafone, Fiji, then

Vodafone, New Zealand both in Auckland

Business Management Conference, Hong Kong

London, UK

Inaugural IT GSCM meeting in Sydney,

Australia

Global Cost Synergies in Bucharest, Romania

London, UK 


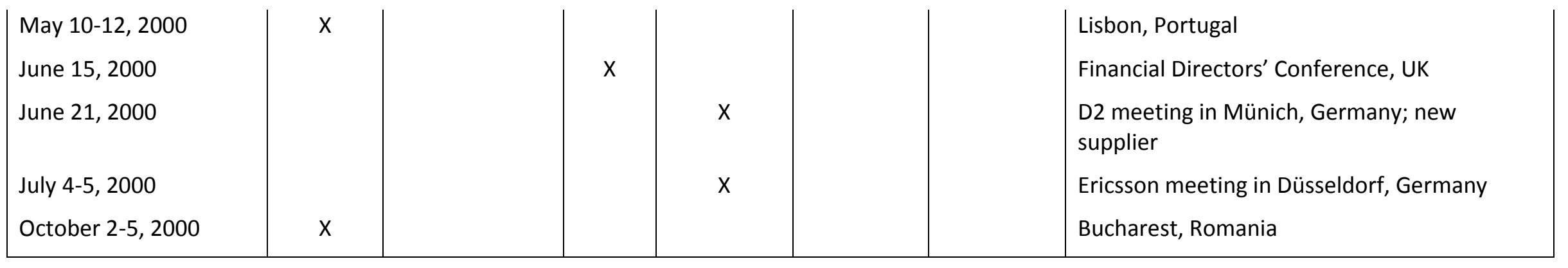

Source: Ibbott (2001) 
Table 2. The key virtual work streams initiated

\begin{tabular}{|c|c|c|}
\hline Key Virtual Work Streams & Brief Description & Lead Country \\
\hline Global agreement & $\begin{array}{l}\text { The creation and agreement of a global 'price } \\
\text { book' that would cover all GSM products } \\
\text { purchased from Ericsson. }\end{array}$ & UK \\
\hline Base station (BTS) configurations & $\begin{array}{l}\text { An agreed convergence towards, and a set of, } \\
\text { BTS configurations }\end{array}$ & UK \\
\hline MSC and BSC switching configurations & $\begin{array}{l}\text { Analysis and discovery of a set of MSC and BSC } \\
\text { configurations that could be adopted by all } \\
\text { countries }\end{array}$ & Greece, transferred later to Germany \\
\hline Groupware & $\begin{array}{l}\text { Analysis and creation of groupware (later known } \\
\text { as eRelationship) for all inter-organisational IS } \\
\text { (Information Systems) that allows information } \\
\text { sharing and product ordering. }\end{array}$ & Netherlands \\
\hline Common software, audit, test and delivery & $\begin{array}{l}\text { The elimination of repeated software build and } \\
\text { testing. }\end{array}$ & Australia \\
\hline
\end{tabular}

Source: Ibbott and O'Keefe (2004) 
Table 3. Composition of actors in the GSCM and eRelationship meetings

\begin{tabular}{|c|c|c|c|c|c|c|c|c|c|c|c|c|c|}
\hline \multirow[b]{2}{*}{ Actor positions } & \multicolumn{7}{|c|}{ GSCM Meetings } & \multicolumn{6}{|c|}{ eRelationship Working Group Meetings } \\
\hline & No. 1 & No. 2 & No. 3 & No. 4 & No. 5 & No. 6 & No. 7 & No. 1 & No. 2 & No. 3 & No. 4 & No. 5 & No. 6 \\
\hline Customer Org.: & & & & & & & & & & & & & \\
\hline Managing Director & 0 & 0 & 0 & 0 & 0 & 0 & 0 & 0 & 0 & 0 & 0 & 0 & 0 \\
\hline Director & 3 & 2 & 1 & 2 & 2 & 2 & 2 & 1 & 1 & 1 & 2 & 1 & 1 \\
\hline Executive & 1 & 2 & 2 & 3 & 7 & 6 & 6 & 1 & 1 & 1 & 1 & 2 & 1 \\
\hline Senior Manager & 2 & 3 & 3 & 8 & 8 & 8 & 13 & 0 & 0 & 0 & 1 & 1 & 0 \\
\hline Other actors & 1 & 3 & 3 & 4 & 3 & 6 & 3 & 1 & 1 & 0 & 1 & 1 & 2 \\
\hline Total in attendance: & 7 & 10 & 9 & 17 & 20 & 22 & 24 & 3 & 3 & 2 & 5 & 5 & 4 \\
\hline Supplier Org.: & & & & & & & & & & & & & \\
\hline Managing Director & 2 & 2 & 2 & 3 & 2 & 2 & 2 & 1 & 1 & 1 & 1 & 2 & 1 \\
\hline Director & 0 & 2 & 2 & 1 & 2 & 2 & 2 & 0 & 1 & 0 & 2 & 2 & 1 \\
\hline Executive & 3 & 3 & 3 & 7 & 8 & 9 & 5 & 1 & 1 & 1 & 2 & 1 & 1 \\
\hline Senior Manager & 0 & 2 & 2 & 7 & 12 & 12 & 16 & 2 & 2 & 3 & 5 & 9 & 2 \\
\hline Other actors & 1 & 1 & 4 & 2 & 1 & 1 & 1 & 0 & 0 & 1 & 0 & 0 & 2 \\
\hline Total in attendance: & 6 & 10 & 13 & 20 & 25 & 26 & 26 & 4 & 5 & 6 & 10 & 13 & 7 \\
\hline
\end{tabular}

Note: The GSCM meetings were the core forum, and the eRelationship Working Group meetings were a subordinated virtual work stream Source: Ibbott (2001) 
Table 4. Summary of Network Orchestration Process

\begin{tabular}{|c|c|c|c|}
\hline Governance Mechanism & Mobilizing Knowledge & Appropriating Knowledge & Fostering Network Stability \\
\hline $\begin{array}{l}\text { Global Supply Chain } \\
\text { Management (GSCM) }\end{array}$ & $\begin{array}{l}\text { Exchange of commercial knowledge and } \\
\text { socialization for a common } \\
\text { understanding } \\
\text { (Pre-supplier and Vodafone meetings } \\
\text { were held in advance of the GSCM } \\
\text { meetings) }\end{array}$ & $\begin{array}{l}\text { Trust formation through social } \\
\text { interaction between the members of } \\
\text { the second author's global team and } \\
\text { operating companies, in particular, } \\
\text { those having direct representation of } \\
\text { the Global Supply Chain Council }\end{array}$ & $\begin{array}{l}\text { Convincing members of a benefit in } \\
\text { maintaining links: the early-day operating } \\
\text { company engagement was based on an } \\
\text { acceptance to act in the community's best } \\
\text { interests; } \\
\text { Drawing the core global team from the } \\
\text { engaged operating companies for } \\
\text { collaborative decision-making and } \\
\text { execution; } \\
\text { Creating the opportunity for participating } \\
\text { operating companies to be the host } \\
\text { location for the GSCM meetings }\end{array}$ \\
\hline $\begin{array}{l}\text { Work streams, in } \\
\text { particular Groupware }\end{array}$ & $\begin{array}{l}\text { Leveraging of resources and horizontal } \\
\text { interaction with other teams in base } \\
\text { companies and the broader joint MNC } \\
\text { communities }\end{array}$ & $\begin{array}{l}\text { Informally motivating the participation } \\
\text { of trusted skilled resources from either } \\
\text { organization that was perceived by the } \\
\text { engaged work stream participants to } \\
\text { add capability to work stream } \\
\text { endeavours }\end{array}$ & $\begin{array}{l}\text { Convincing local and global members of } \\
\text { the economic benefits arising from the } \\
\text { collaboration; } \\
\text { The resource quantum of the quorums } \\
\text { was flexible as to the dynamics of the } \\
\text { leadership }\end{array}$ \\
\hline eRelationship platform & $\begin{array}{l}\text { Exchange of commercial, technical and } \\
\text { operational knowledge and socialization } \\
\text { for a common understanding; } \\
\text { The bi-directional portal was intended as } \\
\text { the embodiment of the business } \\
\text { relationship between Vodafone and } \\
\text { Ericsson that was visible to all in either } \\
\text { organization with corporate intranet } \\
\text { access to encourage convergence of } \\
\text { practice }\end{array}$ & $\begin{array}{l}\text { Encouraging open and unfiltered } \\
\text { communication and access to } \\
\text { information by either organization, } \\
\text { departments or resources therein }\end{array}$ & $\begin{array}{l}\text { Providing for clusters locally to establish } \\
\text { workspaces to manage businesses locally } \\
\text { such as to establish a common set of } \\
\text { country-specific documentation }\end{array}$ \\
\hline $\begin{array}{l}\text { Group Non-disclosure } \\
\text { Agreement }\end{array}$ & $\begin{array}{l}\text { Providing for the release of information } \\
\text { otherwise considered to be confidential }\end{array}$ & $\begin{array}{l}\text { 'Grandfathering' of prior agreement } \\
\text { locally in mitigating matters to be } \\
\text { agreed globally }\end{array}$ & $\begin{array}{l}\text { Achieving transparency through openness, } \\
\text { cooperation and collaboration on matters } \\
\text { such as optimizing processes, } \\
\text { configuration diversity, and acceptance } \\
\text { procedures }\end{array}$ \\
\hline
\end{tabular}




\begin{tabular}{|l|l|l|l|}
\hline Equity-based grouping & $\begin{array}{l}\text { Actively publishing the Vodafone Group } \\
\text { cost synergy ambitions }\end{array}$ & $\begin{array}{l}\text { Engagement of management teams of } \\
\text { each entity with operating companies } \\
\text { for bilateral discussions and } \\
\text { information sharing }\end{array}$ & $\begin{array}{l}\text { Establishing interdependencies among } \\
\text { network members through regular } \\
\text { engagement to stimulate and guide } \\
\text { towards Vodafone Group cost synergy } \\
\text { ambitions }\end{array}$
\end{tabular}

Source: Ibbott (2001) 
Figure 1. Governance Structure

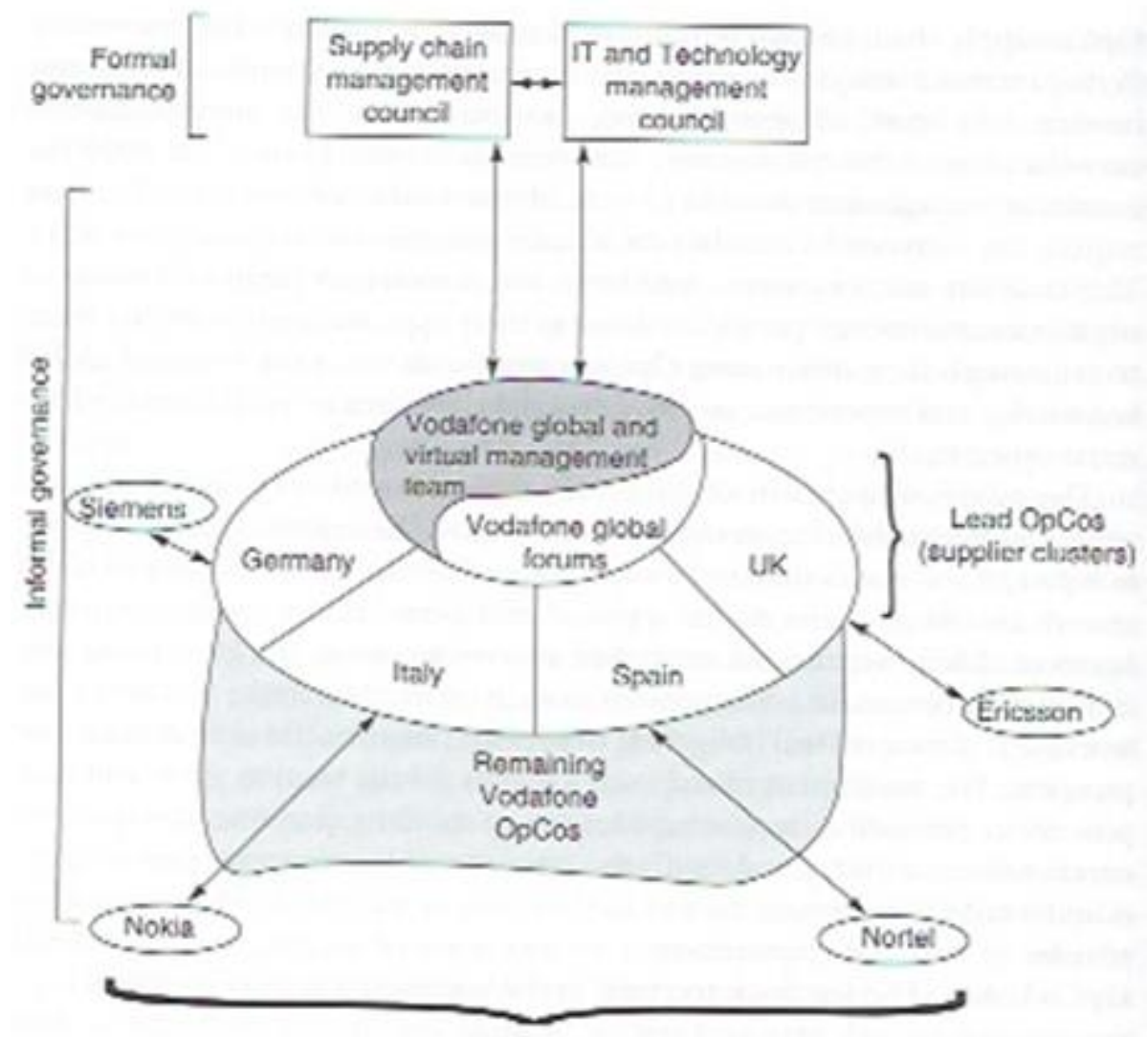

Invisible and virtual organization

Source: Ibbott (2007) 